\title{
APONTAMENTOS HISTÓRICOS SOBRE A FUNDAÇÃO DO ESTADO E A ENTREGA DA TITULARIDADE DA APLICAÇÃ̃O E EXECUÇÃO DA PENA
}

\author{
Daniel Reis Alves dos Santos* \\ Rebeca Henriques Silva Ivo**
}

Resumo: O presente artigo tem como proposta verificar o caminho histórico traçado pelo jus puniendi do Estado no sentido de justificar e legitimar sua exclusiva titularidade. Para tanto, necessário far-se-á estudar, ainda que não esgotadamente por lógica impossibilidade, as teorias culturalista e contratualista de formação do Estado, o porquê de fundá-lo, bem assim analisando o ancestral caráter vingativo da sanção penal que antecede em muito a criação do Estado moderno, para entregar-lhe assim em definitivo a titularidade da aplicação e execução da pena.

Palavras-chave: Jus puniendi; teoria culturalista; teoria contratualista; formação do Estado; titularidade da aplicação da pena.

\section{HISTORICAL STATEMENTS ON THE FOUNDATION OF THE STATE AND THE DELIVERY OF THE OWNERSHIP OF THE APPLICATION AND ENFORCEMENT OF THE PENALTY}

\begin{abstract}
This article has as its proposal to verify the historical path traced by the jus puniendi of the State in the sense of justifying and legitimating its exclusive ownership. In order to do so, it will be necessary to study the culturalist and contractualist theories of State formation, even if not exhaustively by logical impossibility, as to why it is founded, as well as to analyze the ancestral nature of the penal sanction that precedes in a very long time the creation of the modern State, so as to definitively grant him the title of the application and execution of the sentence.
\end{abstract}

Key words: Jus puniendi; culturalist theory; contractual theory; formation of the State; ownership of the application of the penalty.

\footnotetext{
* Mestrando do Programa de Pós-Graduação Stricto Sensu em Direito da UniFG, Guanambi, Bahia, Brasil. Bolsista PROSUP/CAPES. Pesquisador nos grupos de pesquisa Democracia, processo e efetividade do Direito e Centro de Estudos sobre Acesso à Justiça (CAJU). Endereço eletrônico: danielreisalves@hotmail.com.

** Mestranda do Programa de Pós-Graduação Stricto Sensu em Direito da UniFG, Guanambi, Bahia, Brasil. Endereço eletrônico:rebecahenriques@ymail.com.
} 


\section{INTRODUÇÃO}

O presente artigo ocupar-se-á de identificar os argumentos que sustentam e legitimam, consequentemente, o dever-poder-direito de punir participado ao Estado, sendo o mesmo inexecutável pelos administrados, pelas pessoas comuns que compõem esse referido Estado. Dessa maneira, afastar do Estado a aplicação e execução da pena, deixando-as a cargo da vítima ou de quem lhe faça as vezes, como já ocorreu, pode ser perigoso à harmônica coexistência.

Para tanto, é preciso traçar um caminho bastante complexo e denso, muito embora não ser o objetivo esgotar toda argumentação acerca do tema neste artigo, que percorre desde os primórdios com o esclarecimento acerca do surgimento e manutenção do Estado, bem como a fundamentação e sustentação da pena como pura manifestação da vingança (privada, divina etc.), ideia esta sustentada pela Bíblia e por alguns codex antigos.

Nesse ínterim, valendo-se da metodologia dialética de abordagem, do método histórico de procedimento e do levantamento bibliográfico como técnica de pesquisa, será analisada a formação do Estado sob a ótica da doutrina culturalista e contratualista, bem como a pena como expressão do sentimento de vingança.

\section{O ESTADO COMO PRODUTO DA CULTURA}

Como bem leciona o emérito professor Miguel Reale (2000, p. 237), “sem uma substituição da selvageria do homem natural pela nobreza do homem social, não há propriamente cultura”, pois que “o homem inteligente e ativo põe a mão em um objeto para adaptá-lo a uma idéia superior” - que é propriamente a cultura.

Não menos importante de tal trecho, reflete-se a mutação humana para que se alcance a formação do Estado. E é óbvio. A natureza, seguindo aquele entendimento do professor acima lembrado (REALE, 2000), é tão somente tudo o que está ligado ao mundo selvagem, ao ambiente tal qual como foi dado por Deus. E, sendo o Direito produto surgido através da cultura humana, este também está intrinsecamente ligado à história do homem sob os ângulos da Sociologia Jurídica, e, ainda, em detrimento do seu caráter coexistencial, traduz-se o Direito, como bem raciocinou Jhering, na política da força, provando-se este raciocínio por meio da passagem do professor Reale, fundamentando o Direito como “a vida pela coação, até onde não 
é possível a vida pelo amor; a força que matou a própria força; uma das peças de torcer e ajeitar o homem da natureza em proveito da sociedade...” (REALE, 2000, p. 237).

Entender a sociologia jurídica é fundamental para o profissional do Direito, posto que a relação entre este e o ser humano é da sua essência política (PEDROSA, 2006). Neste ponto, ensina o professor Sérgio Cavalieri Filho, em citação literal feita pelo catedrático Ronaldo Leite Pedrosa, que "o direito é um fato social, e tem a sua origem nas inter-relações sociais. É um fenômeno social decorrente do próprio convívio do homem em sociedade” (CAVALIERI FILHO, 1996 apud PEDROSA, 2006, p. 33).

E sobre a teoria do Estado como meio e como fim, relembra Miguel Reale (2000, p. 238) a lição do eminente clássico Tobias Barreto, quando este afirma o Estado “como realizador da ordem jurídica e fomentador de bens de cultura: 'O Estado é fim ao mesmo tempo que é meio, porque a ordem social, a cultura humana de que ele é órgão, constituem o seu mesmo fim. O seu fim é o seu meio'”.

A contrario sensu do que propunha Tobias Barreto, que defendia a Cultura como um problema filosófico, Silvio Romero e Clóvis Beviláqua transferem tal problema à seara sociológica (REALE, 2000, p. 239), vendo-se, outrossim,

na cultura mero prolongamento da natureza, visto como o homem não teria podido produzir a sua culttura, conforme seus desejos e caprichos: o homem é o que é, o que as leis cósmicas o deixaram ser e, neste sentido geral, a civilização, com o que ela tem de mais elevado, é produto da natureza.

Clóvis Beviláqua, cujo raciocínio sobre o tema radicalmente firmou-se contra o discutido pelo emérito Tobias Barreto, sendo que, para aquele, o Estado e o Direito jamais poderiam ser concebidos como produto da cultura humana concomitantemente à existência de uma lei natural do direito (REALE, 2000, p. 240).

Com a devida vênia dos referidos doutos, e de modo algum desconsiderando o postulado deixado, coerente parece ser a afirmativa do Direito como produto da cultura, e não prolongamento da natureza, embora seja de fato um fenômeno social, tendo em vista que a cultura é tudo aquilo modificado pelas mãos humanas, e gerido pela sua gigante inteligência e adaptação, e que, como em nenhum outro animal, é dotado de racionalidade. E, adaptando-se o homem à natureza com fito na melhora de sua própria qualidade de vida, ele assim cria a cultura; criando a cultura, ele modifica a natureza, e se houver outro homem (formando a coexistência local), nascerá o Direito (fato social); e a partir da existência do Direito, o homem garante sua 
segurança em relação aos demais homens, que, por serem políticos (antrhopos zoon politikin preceito aristotélico), necessitam coexistir para se realizarem, mas tal coexistência torna-se pacífica quando eles utilizam a força legítima, lembrando Jhering dito acima, a força oriunda do Direito, e este nada mais é do que a "política da força”.

Apreendido o Direito e o Estado como resultados da vontade da cultura humana, ou simplesmente da Teoria Culturalista, eis que se torna oportuna a orientação acerca da fundamentação da existência do Estado, suas vantagens e desvantagens, para, daí então, ser entendido e explicado o porquê do jus puniendi do Estado, direito de punir este que, aliás, tornase um dever e, também, um poder de punir inquestionável pelos seus administrados.

\section{FUNDAMENTOS DA CRIAÇÃO DO ESTADO}

Vê-se que o homem natural vive inerte em relação às coisas a ele dadas pela natureza, e que o homem culto, contrario sensu, é aquele que adapta tais coisas naturais para utilizá-las, de uma forma ou de outra, em proveito próprio ou para a fruição de outro homem. Tendo a distinção do homem natural com o homem nobre proposta pelo saudoso Miguel Reale (2000), também caminha ao entendimento de que o Direito (assim como o Estado) é produto eminentemente da cultura, e que o Estado se forma pela necessidade de que os homens sentem ao se depararem com situações de conflitos de interesses entre seus iguais, mas que, dominados pelas paixões naturais, são incapazes de ponderar a situação e compor com justiça o conflito.

Thomas Hobbes (19--?) de Malmesbury intriga com autenticidade o natural prazer que os homens experimentam ao sentirem-se livres e dominadores sobre outros homens. E que a conservação e a satisfação da própria vida é o fundamento precípuo deles viverem num Estado. Pois, ao contrário, debater-se-iam em guerra até sua extinção, pois não há um poder intimidador, castigador, capaz de oprimir e coibir práticas de quebra contratual, seja na seara cível, como na criminal... E daí os demais ramos do Direito.

O homem é um ser naturalmente invejoso, orgulhoso, e tais paixões colidem com o que ele realmente deseja que lhe seja feito pelos seus semelhantes. Nessa interpretação, seriam o Estado e as leis por ele produzidas, as armas que tornam os homens justos, humildes, bons, pacientes etc. Ou melhor: o que de fato ocorre é a repressão das paixões naturais, com o objetivo de satisfação do bem comum. Mas o Estado - que garante a paz, a justiça, a segurança... - não é constituído por certo tanto de pessoas, pois, se assim fosse, outro certo aglomerado pouco 
superior teria a força sobre aquele menor, continuando a prevalecer o impulso das paixões (HOBBES, 19--?).

Assim, a necessidade de se criar o Estado, e entregar-lhe parte de sua liberdade, dá-se devido ao fato de que o aglomerado de pessoas, supra referido, é incapaz de ser, natural e consecutivamente, justo, honesto, caridoso (dentre outras leis naturalistas) (HOBBES, 19--?). Por isso que o aglomerado deve ser organizado e submetido a um poder central e unânime, um governo civil, que imponha a ordem, cujo descumprimento sujeite o infrator à sanção, mas sua obediência a ele e a todos beneficia no tocante à boa convivência, à harmoniosa coexistência, em nome do bem público, do interesse coletivo, daquelas pessoas que compõem o aglomerado governado (Estado).

Por liberdade deve-se compreender a "capacidade que tem o homem de realizar um plano a si mesmo proposto” (REALE, 2000, p. 234); ou, consoante o que se apreende do dicionário Priberam: “direito de proceder conforme nos pareça, contanto que esse direito não vá contra o direito de outrem”, “condição do homem ou da nação que goza de liberdade”, “conjunto das ideias liberais ou dos direitos garantidos ao cidadão”, “desassombro” etc. Assim, trata-se a liberdade de tudo o que o homem pode fazer nos limites dos seus direitos. Ora, o homem livre está, percebe-se, encarcerado na sua liberdade.

“Liberdade”, nas palavras de Thomas Hobbes (HOBBES apud REALE, 2000, p. 73), “significa, em sentido próprio, a ausência de oposição”. Para este, trata-se a oposição aqui estudada de "impedimentos externos do movimento" e exemplifica que "tudo o que estiver amarrado ou envolvido de modo a não poder mover-se senão dentro de determinado espaço, sendo esse espaço limitado pela oposição de algum corpo extremo", tem sua "liberdade de ir mais além” restringida. A libertas, consoante o que se apreende da análise do Direito Romano, trata-se do bem mais precioso do homem, tanto que é ela que distingue os seres humanos dos escravos, isto é, o homem livre é ser humano, o escravo é res, coisa, segundo o raciocínio de Justiniano (CRETELLA JÚNIOR, 2005), estar-se-ia, quando se tratar do escravo, diante de um ser considerado sem cabeça (no sentido de ser incapaz de pensar ou de não possuir alma), logo não era uma pessoa.

Continua, Thomas de Malmesbury, na explicação citando o homem enfermo e uma pedra (cuja inércia é inerente à sua própria natureza) como corpos que não se movem por lhe faltarem este poder, ou seja, por um impedimento interno; assim, não há que se falar em 
restrição da liberdade, isto é, por não se concretizar um obstáculo externo à vontade deles (HOBBES, 19--?.).

Entendido o significado de liberdade, Hobbes ensina que o "homem livre é aquele que, naquelas coisas que graças a sua força e engenho é capaz de fazer, não é impedido de fazer o que tem vonta de de fazer” (HOBBES, 19--?., p. 73). No entanto, o homem livre às vezes se priva de usar de sua liberdade bloqueado pelo medo que sente de perdê-la. É por este motivo que o homem submete-se à legislação estatal, para não perder sua liberdade, procurando conservar, por meio do medo, seu estado de livre. É, pois, o medo das consequências negativas oriundas da lex que o homem se prende em sua própria liberdade, embora seja livre para contrariar aquela.

Assim, então, seria ingênuo pensar o Estado como uma criação humana oriunda da nobreza dos homens que, de livre e espontânea vontade, cedem parte da liberdade de que julgam ter, para, preocupados com o bem geral dos semelhantes, fundarem uma pessoa maior com um poder central e geral. Não! O Estado, em consonância com a inteligência de Blackstone (1822 apud REALE, 2000) infra, surge a partir do reconhecimento dos próprios homens sobre sua fraqueza, imperfeição, vulnerabilidade, incompletude; os homens são obrigados a cederem parte de sua liberdade para que o Estado surja e, com sua poderosa mão, aparte qualquer conduta que julgar injusta - pois justiça é valor, e valores cada Estado tem os seus na medida de seus respectivos interesses.

\section{SURGIMENTO DO ESTADO SOB A ÓTICA DA TEORIA CONTRATUALISTA}

Resta, indubitavelmente, entendida e compreendida a necessidade, a precisão, dos homens se organizarem e se submeterem a um poder central, trocando sua liberdade individual pela liberdade coletiva; lembrando que, no statu quo, a liberdade individual do homem tinha um preço muito caro: a perigosa e incessável vigilância, o medo constante de morrer violentamente e de ter de, para permanecer vivo, também com violência matar. Na liberdade coletiva, todavia, o homem limita-se à obediência de normas legais que regem o respeito ao direito de outrem e, assim, os outros também respeitam seus direitos (vida, liberdade, patrimônio, honra etc...), pois, como foi alhures visto, há um medo muito forte de deixarem de ser livres. 
Pois bem. Idealizado o Estado sob o ponto de vista da cultura, tendo como pressuposto a troca de liberdades pelo homem (porque a criação do Estado, em poucas palavras, nada mais é do que apenas isso), eis o momento de entendê-lo sob os ângulos da teoria contratualista. Todavia, é imprescindível analisar a teoria naturalista da formação da sociedade e, depois, do Estado para melhor apreender aquela.

A teoria naturalista apresenta-se coesa quanto à espontaneidade dos homens na formação da sociedade. Ora, pois, é indubitável que a primeira sociedade naturalmente formada foi (é) a família. A constituição de um Estado pressupõe a existência de uma sociedade, pois esta não requer organização político-administrativa, o contrário daquele. Como bem explica abaixo São Tomás de Aquino, e seguindo seu entendimento, enquanto o homem necessitar dos seus semelhantes, ele os usará; porém, não mais precisando, eliminá-los-á; isto só não ocorrerá se o homem estiver preso em sua liberdade cedida ao Estado, o que o impedirá de eliminá-los (PEDROSA, 2006). Dessa forma, infere-se que a coexistência apenas será harmônica caso o interesse individual daqueles que compõem a comunidade ou a sociedade estiver resguardado e for satisfeito.

Tem como registro inicial da defesa desta teoria o filósofo Aristóteles, aquele que afirmou o homem como ser naturalmente sociável; já na Idade Média o principal defensor foi São Tomás de Aquino, consoante o qual “o homem se agregava por necessidade, e não por opção”(PEDROSA, 2006, p. 34). E assim surgia a sociedade, como expressão das necessidades devido à limitação humana; depois, o Estado, para organizar politicamente tal agrupamento de pessoas e mantê-lo mesmo que tal necessidade já tenha sido suprida.

O professor Ronaldo Leite Pedrosa (2006, p. 34), explicando a formação da sociedade sob a ótica da teoria contratualista, leciona que “a sociedade aparece no momento em que, após o mero agrupamento, neutro, organiza-se o conjunto, mediante a aceitação tácita de regras de convivência”. Assim, a teoria contratualista (teoria do contrato primitivo ou do contrato originário) interpreta a sociedade como um aglomerado de pessoas que se forma a partir da ratificação, de forma tácita, de normas de convivência, sendo que o mero agrupamento, sem esta ratificação, é o entendimento e defesa da sociedade segundo a teoria anteriormente vista.

Tem como precursor o filósofo Platão, desenvolvendo-se a teoria contratualista na Idade Média, por meio dos estudos de Thomas Hobbes. Mais tarde, teoria esta explicada por John Locke e J. J. Rousseau. Estes teóricos refletem a tríade da teoria contratualista, consoante a qual afirma ser impossível a agregação de que trata São Tomás e, negando ainda, a 
politicidade do homem, conforme entendia Aristóteles, uma vez que, embora imperfeito e necessário à sua realização pessoal, “os homens não nascem com a inclinação à sociedade. Ao oposto..., o homem, em estado puro de natureza, coloca-se em constante estado de guerra, daí surgindo o acordo social...” (PEDROSA, 2006, p. 36).

Hobbes, filósofo materialista, afirmava o homem como ser naturalmente maligno (hominis lupus hominis); defensor do absolutismo, concorde neste ponto com Nicolau Maquiavel (PEDROSA, 2006). Mas, dentre as faculdades que o homem acumula, a razão é uma delas e é sobre esta que, contrariamente ao ser político de Aristóteles, prevalece a inclinação humana a unirem-se racionalmente, pelo interesse à própria preservação, formando assim o Estado (HOBBES, 2006).

John Locke, contra o absolutismo e defensor da propriedade privada, é um contratualista que, na sua essência, torna-se partidário (ou crente) da teoria naturalista. Este teórico político usa da lógica para explicar tal fenômeno: “o homem foi criado por Deus com necessidades previamente estabelecidas, que o levou à vida em grupo, por ser de sua natureza” (PEDROSA, 2006, p. 35). Embora esta transcrição demonstre certa crença na formação natural da sociedade (e, como consequência, do Estado), sua defesa de tal formação pela via contratual / racional concomitante com sua oposição ao absolutismo ilimitado é perceptível ao expor seu pensamento acerca da racionalidade humana, de acordo com a qual "os homens cediam sua liberdade em prol de um governo, mas, acaso esse governo usurpasse seus poderes, o homem poderia retomar o seu próprio poder, originário e inalienável” (PEDROSA, 2006, p. 36).

Jean-Jacques Rousseau, iluminista francês, concordava com Locke acerca do sistema de governo absolutista, porém foi um crítico incisivo da propriedade privada, rabisca preceitos democráticos, segundo o qual pertence a soberania do Estado ao povo que o compreende (ROUSSEAU, 19--?).

O catedrático Miguel Reale, em consonância com o pensamento de Jellinek, aponta a inderrogável importância da Teoria Contratualista na constituição do Estado Moderno. O referido autor, insistindo em nota de rodapé de sua obra, expõe afirmativa de Jellinek, feita nos meados de 1793, segundo o qual lembra o obtempero de J. G. Fichte a J. J. Rousseau, sendo que o primeiro "publicara uma obra juvenil, reclamando não só uma interpretação mais exata do contratualismo de Rousseau, como também acentuando a sua natureza exclusivamente racional” (REALE, 2000, p. 139). 
À luz da razão (lembrando que o século XVIII, em que Jean-Jacques Rousseau viveu, foi denominado pela História como o século das luzes, por excluir a explicação de todos os fenômenos, naturais e sociais, pela Igreja, segundo uma autoridade indelével e indiscutível à qual todos, inclusive o rei, estava submetido, racionalizando a existência e as relações humanas e das coisas - movimento este que recebeu a denominação de Iluminismo), o autor de Emílio e Contrato Social, despido de dados históricos sobre fusão das vontades humanas concorrendo à criação do Estado-nação, explicita seus sentimentos e sua percepção acerca do controvertido tema. Para ele, como o homem é o único animal que detém a façanha de utilizar a razão (e, neste ponto, vale lembrar, concorda com Thomas Hobbes acerca da razão como sendo um elemento natural do homem), ou seja, é racional, logo seria ele suficientemente inteligente a juntar com seus semelhantes mediante a legislação e aceitação (abstratas) de normas que regulassem suas condutas, e, assim, garantindo a todos a vida com segurança (ROUSSEAU, 19--?).

Destarte, pode-se inferir que a ideia defendida por Thomas Hobbes é traduzível no medo da insegurança; enquanto que aquilo apadrinhado por Jean-Jacques Rousseau é inferido como a insegurança pelo que tem medo.

Ainda em obtempero com Rousseau, porém na mesma inteligência de Jellinek, Blackstone (1822 apud REALE, 2000, p. 139) afirma que a origem das sociedades não provém

formalmente de convenções de indivíduos determinados pela necessidade e pelo medo, é, contudo, o sentimento de sua fraqueza e de sua imperfeição que mantém os homens em sociedade, que lhes demonstra a necessidade dessa união e que é, por conseguinte, o fundamento sólido e natural, assim como o cimento da sociedade civil. E é isso que nós entendemos por contrato social primitivo.

Blackstone, ademais, desacredita na doutrina que afirma o contrato social como um instrumento formalmente redigido com fito na formação e organização do Estado, posto que na História não se identifique tal façanha (BLACKSTONE, 1822 apud REALE, 2000, p. 139). Diga-se, aliás, que aparenta ser justa esta conclusão, uma vez que, de fato, há este “contrato” entre as pessoas de determinado território, porém não necessariamente redigido num espaço físico e assinado por todos, pois assim, ainda, se não houvesse uma imposição natural que convirja a tal ratificação, não calaria as paixões humanas malignas de que trata Thomas Hobbes. Por isso, torna-se imprescindível o entendimento de que o “contrato” seja um ideário 
abstratamente ratificado pelas pessoas, quase que por coerção interna e pessoal, submetendo-se estas às leis da Ciência do Direito.

Com esta afirmativa do último período do parágrafo imediatamente supra, observa-se, de logo, que o contrato que origina o Estado nada mais é do que um “conceito racional prático, e não empírico” (REALE, 2000, p. 144). Esta ideia pensada pelo professor Miguel Reale e anteriormente citada não deixa de refletir a inteligência de Immanuel Kant, consoante o qual considera contrato originário (Blackstone, aqui, denomina contrato social primitivo) a abstração usada pelas pessoas apta a fomentar a vida constituída (o que Kant chama de legitimidade) da pessoa do Estado, sendo que para tanto independerá de instrumento ratificado fisicamente e ainda assim manterá sua validade legítima. Tal abstração, em sede de esclarecimento, deve ser entendida, como bem leciona o professor Miguel (REALE, 2000, p. 144), “a simples idéia do ato [...] da realização de um contrato”, e não propriamente o ato, não necessariamente a redação e a assinatura de tal contrato, determinando, destarte, “o princípio da organização político-jurídica”.

Enfim, é-se oportuno transcrever o raciocínio apreendido da monografia de Immanuel Kant (apud REALE, 2000, p. 145), na qual o autor aponta o contrato originário - ou contrato social primitivo - como um instrumento

sobre o qual tão-somente se poderá fundar entre os homens uma constituição civil e,
por conseguinte, inteiramente jurídica, instituindo-se uma entidade comum. Esse
contrato especial, denominado contractus originarius ou pactum sociale, como
coalizão de todas as vontades particulares e privadas de um povo em vista de uma
vontade comum e pública, no escopo de uma legislação puramente jurídica [...], não
precisa, porém, ser absolutamente pressuposto como um fato [...], o que, aliás, seria
impossível, como se, antes de mais nada, fosse necessário provar, à luz da História,
que um povo, em cujos direitos e obrigações nós entramos como posterioridade, haja
realmente concluído outrora um ato dessa natureza, dele nos deixando, oralmente ou
por escrito, uma notícia ou documento que nos permita julgarmo-nos ligados a uma
constituição já existente.

Pois bem, entendido que o contrato originário se trata de uma ideia racional, é não menos importante apreender que esta "idéia de razão [...] possui sua realidade prática incontestável” (REALE, 2000, p. 145) que exige determinadas condutas por parte dos governados (entendimento semelhante ao de Del Vecchio e Höffding, segundo lições de Miguel Reale), pois transcende do imaginário humano e passa à vida cotidiana, sendo que as leis são impostas a todos os cidadãos que ratificaram abstratamente o contrato; contradizendo aparentemente o ideário de que há um consentimento mútuo na formação do Estado, as pessoas 
são submetidas à obediência e observância da legislação, que passa a ser imposta objetivando não apenas o bem comum, mas a manutenção de uma ordem de pacificação social. De outro modo, não teriam legitimidade os governantes, quando na direção da máquina estatal.

Nota-se em Del Vecchio, em concordância com essa negativa da existência de um contrato segundo uma redação física, chegando a afirmar, talvez com exacerbado exagero, que “a sociedade é, especialmente em suas origens, independente de toda livre escolha” (DEL VECCHIO apud REALE, 2000, p. 142).

Em suma, enquanto Rousseau (19--?) afirma a existência da sociedade mediante um acordo mútuo de vontades livres e individuais, Del Vecchio (apud REALE, 2000) obtempera acreditando que a sociedade existiria mesmo sem o "pluriconsentimento" retro referido das pessoas que compreendem o território geográfico. E essa situação reafirma o já analisado caráter coercitivo do Estado para com seus governados, visto que se tratam estes de seres fracos, incompletos, imperfeitos, que necessitam se unir para se realizarem individualmente, bem como, em razão do medo, para não perecerem violentamente.

Immanuel Kant e Jean-Jacques Rousseau, em drástica discordância com Thomas Hobbes de Malmesbury, entendem o homem em sua natureza como um ser puro, limpo de qualquer paixão maligna, justo, solidário (todos concordam entre si que o homem naturalmente se dota de razão, sendo, portanto, um ser racional). Enfim, enquanto que para este só se é possível alcançar tais virtudes com a imposição das leis elaboradas por um ordenamento político-jurídico, para aqueles, em especial para o filósofo iluminista, a razão (para Hobbes não é a razão, e sim a lei), o bom senso é que impulsiona o bom (ou mau) uso das paixões humanas; aliás, o mau uso das paixões instintivas do homem por si resulta da própria convivência em sociedade política, visto sua formação desigual e, concomitantemente, ofertando privilégios a uns homens, e daí surge a necessidade de impô-los normas de conduta (REALE, 2000).

\section{A PENA COMO FORMA DE VINGANÇA}

Ubi jus, ibi societas; ubi societas, ibi jus. A nascente do Direito em si confunde-se com o surgimento da sociedade; esta que, por óbvio, antecede à criação do Estado. Pois, como reluz na frase em latim: onde houver o direito, haverá sociedade; e onde houver sociedade, haverá o direito. A sociedade e o Estado, como analisado, surgem da união e ou solidariedade 
egoísta dos homens frente à sua própria fraqueza. Destarte, assim também ocorre com o Direito (Penal).

Esta é uma das frases que melhor traduz a nascente do Direito. Dela pode-se abstrair que o Direito passa a existir a partir do momento em que o homem encontra outro homem, passando a dividir com ele seu espaço. Clássico exemplo aquele que relembra o náufrago, enquanto vivia solitário numa ilha deserta, não haveria que se falar em observação do Direito, aliás, de nenhum tipo de norma, seja religiosa, moral etc. No entanto, quando este náufrago depara-se com um semelhante, ambos deverão respeitar o espaço um do outro, sob pena de iniciar-se um conflito sangrento.

Dessa forma, nascendo o Direito da necessidade que mais de uma pessoa no mesmo espaço têm para viverem harmonicamente, é razoável, como já visto antes, considerá-lo produto da cultura. Este problema jusfilosófico, cujo esgotamento de sua análise não é o que se objetiva, parece encontrar-se bastante debatido.

Perceba o quantitativo da vingança penal, como retribuição negativa a uma desobediência, o fato bíblico: Deus fez Adão e Eva, e a eles Deus ofereceu tudo o que o Paraíso possuía. Porém, havia uma proibição, que recaíra sobre a árvore do conhecimento, sobre a maçã. Ao desobedecerem a Deus, comendo o fruto proibido, Ele aplicou a primeira resposta penal de que se tem notícia, expulsando-os, Adão e Eva, do Paraíso, tendo como efeitos secundários da pena o fato de terem de produzir o próprio alimento, sentir dores e demais intempéries próprias da natureza humana (GRECO, 2008).

Então, perceba, a Bíblia traz a primeira pena, que tem caráter, evidentemente, de vingança, mas um tipo especial: a divina.

Didaticamente, é-se aplicada a vingança divina como forma de resposta criminal ao agente que transpõe a leis de modo a macular as pseudo-divindades; e isto em qualquer fase da crença no divino, seja no mono ou no politeísmo. E, sendo os “deuses” os sujeitos passivos dos atentados criminosos, nada mais esperado do que a aplicação das penas fosse de titularidade inquestionável dos sacerdotes, que as aplicavam, se comparado com o sistema penal garantista hodierno, rodeadas de vícios de legalidade, proporcionalidade, humanidade, razoabilidade etc. Interessante é que as penas, em suma cruéis e corporais, buscam inflamar, sangrar, a alma do condenado (CAPELA, 2002).

A fase da vingança divina é facilmente notada na era medieval, quando a Igreja aplicava sanções corporais segundo uma legitimidade obscura. 
A vingança privada é melhor identificada na Idade Antiga e na Pré-História, se for considerado o ‘privado’ como a não interferência na aplicação da pena de qualquer ente externo à relação criminoso / vítima (o Estado, o rei, o juiz, ou qualquer outro ente com uma posição equidistante, ou não, das partes). Pois veja: nesse momento, a defesa dos interesses individuais deve ser efetivada pelas próprias partes envolvidas e, na ausência de uma delas, pelo seu sucessor (CAPELA, 2002).

Na fase primitiva da "vingança privada não regulamentada”, a poena, que era imposta ou pela vítima ou por sua família, era totalmente desprovida de proporcionalidade $^{1}$ ou metodologia, era aleatória e sem limites, tornando o sujeito ativo do crimen em sujeito passivo de outro delito. A responsabilidade penal era solidária, estendia-se a todos do grupo e a sanção era tida como uma vingança de sangue; segundo a doutrina, “a primeira manifestação da cultura jurídica” (MIRABETE, 2008, V. 1, p. 244). Mas não se pode, todavia, questionar nem cogitar a injustiça dos atos, uma vez que na época estes eram os valores que dominavam a sociedade.

Nesses moldes, o Código de Hamurábi (século XVII a. C.), o Pentateuco de Moisés no século XIV antes de Cristo e, mais recentemente, a Lex Duodecim ou, simplesmente, Doudecim Tabulae (Lei das XII Tábuas - datada do século V a. C.), caminharam para um mesmo fim: a vingança privada baseada na exata igualdade da lesão e sem nenhuma ideia de ressocialização do culpado, porém já com um mínimo sentimento de proporcionalidade, o que fez limitar a então desmedida aplicação de uma sanção ou retribuição penal. Roma era habitada por uma população violenta, que em muito, ou tudo, se justificava a dura aplicação da Lex Duodecim.

O Código de Hamurábi ${ }^{2}$ serve alguns exemplos que merecem ser lembrados. No Capítulo XII, o Código trata dos "Delitos e Penas (Lesões Corporais, Talião, Indenização e Composição)":

$196^{\circ}$ - Se alguém arranca o olho a um outro, se lhe deverá arrancar o olho.

$197^{\circ}$ - Se ele quebra o osso a um outro, se lhe deverá quebrar o osso. [...]

$200^{\circ}$ - Se alguém parte os dentes de um outro, de igual condição, deverá ter partidos os seus dentes.

\footnotetext{
${ }^{1}$ A Lei de Talião, Lex esta que torna a vingança privada regulamentada, abrandou esse estado de primazia do direito penal sancionatório, posto que, embora superficialmente, se comparado com a atualidade, adveio-se uma faísca do que, mais tarde com o Marquês de Beccaria, seria denominado princípio da proporcionalidade.

${ }^{2}$ Sua referência encontra-se mencionada infra no espaço correspondente.
} 
Extrai-se, além destes fragmentos, do Código de Hamurábi a interpretação, precisamente dos itens $209^{\circ}$ e $210^{\circ}$, de que se alguém bater em uma mulher livre e ela morrer com seu feto, o filho do agressor deverá ser morto (negação do atual princípio da pessoalidade da pena: cláusula pétrea positivada no inciso XLV, do art. $5^{\circ}$, consoante o qual “nenhuma pena passará da pessoa do condenado...”).

E, no Capítulo XIII (CÓDIGO DE HAMURÁBI), que trata dos "Médicos e Veterinários; Arquitetos e Bateleiros (Salários, Honorários e Responsabilidade)”, assim está previsto: “229 - Se um arquiteto constrói para alguém e não o faz solidamente e a casa que ele construiu cai e fere de morte o proprietário, esse arquiteto deverá ser morto. 230 - Se fere de morte o filho do proprietário, deverá ser morto o filho do arquiteto”.

Partindo para a Teologia, ciência que, dentre outras teorias, há conclusão segundo a qual Moisés fora o autor do Pentateuco, identifica-se linhas da vingança privada.

Gênesis, Êxodo, Levítico, Números e Deutoronômio. Os cinco primeiros Livros da Bíblia do Antigo / Velho Testamento, compõem o Pentateuco. O terceiro Livro, Levítico, bem traduz o que se espera desta discussão no seu Capítulo 24 (BÍBLIA):

17. Quem matar a alguém, certamente será morto;

18. e quem matar um animal, fará restituição por ele, vida por vida.

19. Se alguém desfigurar o seu próximo, como ele fez, assim lhe será feito:

20. quebradura por quebradura, olho por olho, dente por dente; como ele tiver desfigurado algum homem, assim lhe será feito.

21. Quem, pois, matar um animal, fará restituição por ele; mas quem matar um homem, será morto.

A Lei das XII Tábuas é resultado de inúmeras batalhas entre patrícios e plebeus, sendo que estes questionavam a igualdade entre ambos. De certo que a essência de sua redação já era aplicada em tempos mais remotos ainda. Ela marca o início da codificação das leis romanas, da certeza e da segurança jurídicas. O professor José Cretella Júnior (2005, p. 33.), sustentado na inteligência do historiador Tito Lívio, chega a afirmar que a Lei das XII Tábuas nada mais é do que a "fonte de todo direito público e privado" 3 . Tome como exemplo a Tábua Sétima (A LEI), que trata dos delitos: conforme o item de número 10, a pessoa que difama outra com palavras ou cânticos, será fustigada, isto é, será castigada, chicoteada, apanhará com vara flexível, chibata, junco... (DICIONÁRIO); o item 11, por sua vez, afirma que se uma pessoa ferir outra,

\footnotetext{
${ }^{3}$ Expressão esta que se traduz da frase latina “fons omnis publici privatique juris”.
} 
aquela deverá sofrer a pena de Talião, mas o delito poderá ser objeto de "transação penal"4, excluindo a aplicação de tal pena.

\section{CONCLUSÃo}

Do apanhado histórico e de toda a análise da doutrina específica que trata da dogmática e da história do Direito e do Estado, infere-se que, de certa forma, não seria viável uma regressão, partindo do estado atual das coisas, à exclusão da titularidade do Estado para a aplicação e execução da pena.

Não cabem dúvidas no sentido de que o Estado surge da necessidade do homem em se realizar, cedendo a sua liberdade individual, mesmo contra esta cessão (e aqui não se apresenta coerente a teoria segundo a qual o homem ratifica espontaneamente o contrato social), submetendo-se às normas de conduta. O medo de lhe ser subtraída a sua liberdade o dirige à convergência com os ditames deste Estado criado. Assim, há uma coerência em fundamentar o surgimento e a manutenção do Estado e do Direito sob a ótica culturalista, nada obstante a racionalidade inerente à condição humana permite-lhe associar-se com o intuito de se promover e se manter, mas, lembrando, submisso ao medo de perder não apenas sua liberdade, mas de morrer violentamente.

O jus puniendi, que, na verdade e na ordem, trata-se de dever-poder-direito de punir legitimado ao Estado através da cessão das liberdades individuais que somente se realiza na subserviência do bem geral da sociedade. Dessa maneira, ressalvadas as exceções legais, seria catastrófico a entrega desse múnus público a uma pessoa natural, pois, se assim fosse, as respostas penais viriam viciadas de injustiça em todos os sentidos. Deste modo, a vingança privada demonstra perfeitamente o perigo de entregar a uma pessoa natural a manipulação do jus puniendi.

Deve, por fim, ser entendido que o jus puniendi é indelegável e intransferível do Estado. E mais, acredita-se, com base nos estudos, que o primeiro Código Penal da História da Humanidade é representado pelas escrituras do Código de Hamurábi, complementado pelo Pentateuco de Moisés.

\footnotetext{
${ }^{4} \mathrm{O}$ texto original do item 11 não fala em transação penal, porém parece coerente a interpretação acerca da palavra “acordo” nele mencionada.
} 
Ao ceder suas liberdades em prol da criação do Estado, o homem inescusavelmente renuncia de forma absoluta e irrevogável aquele estado primitivo no qual a ele, individualmente, cabia a imposição da sanção penal ora que julgasse melhor, ora determinada por um conjunto de Códigos. De mais a mais, por esta mesma razão, o Estado, como senhor absoluto da organização político-administrativa, ainda que o exercício do poder seja tripartido, como o é, mantém-se como titular exclusivo da aplicação e do cumprimento da sanção penal.

\section{REFERÊNCIAS}

A LEI das XII tábuas. Recanto das Letras. Disponível em: <http://www.recantodasletras.com.br/textosjuridicos/2649327>. Acesso em: 10 jan. 2018.

BÍBLIA. Português. Bíblia sagrada. Tradução de Padre Antônio Pereira de Figueredo. Rio de Janeiro: Encyclopaedia Britannica, 1980. Edição Ecumênica.

CAPELA, Fábio Bergamin. Pseudo-evolução do direito penal. Jus Navigandi. Disponível em: $<$ http://jus.com.br/revista/texto/2795/pseudo-evolucao-do-direito-penal>. Acesso em: 10 jan. 2018.

CRETELLA JÚNIOR, José. Curso de direito romano: o direito romano e o direito civil brasileiro no Novo Código Civil. 29. ed. rev. e aum. Rio de Janeiro: Forense, 2005.

CÓDIGO de Hamurabi. Cultura Brasileira. Disponível em: <http://www.culturabrasil.pro.br/hamurabi.htm>. Acesso em: 10 jan. 2018.

DICIONÁRIO Priberam da Língua Portuguesa. Priberam. Disponível em: $<$ http://www.priberam.pt/DLPO>. Acesso em: 10 jan. 2018.

GRECO, Rogério. Curso de direito penal. 10. ed. Rio de Janeiro: Impetus, 2008.

HOBBES, Thomas. Do cidadão. São Paulo: Editora Martin Claret, 2006.

HOBBES, Thomas. Leviatã ou matéria, forma e poder de um estado eclesiástico e civil. Tradução de João Paulo Monteiro e Maria Beatriz Nizza da Silva. [S.I.: S.n.], [19--?].

MIRABETE, Júlio Fabbrini; FABBRINI, Renato N. Manual de direito penal: Parte geral, arts. $1^{\circ}$ a 120 do CP. 24. ed. rev. e atual. São Paulo: Atlas, 2008, V. 1.

PEDROSA, Ronaldo Leite. Direito em história. 5. ed. rev. ampl. e atual. Rio de Janeiro: Lumen Juris, 2006.

REALE, Miguel. Horizontes do direito e da história. 3. ed. rev. e aum. São Paulo: Saraiva, 2000. 
ROUSSEAU, Jean-Jacques. Do contrato social. Tradução de Rolando Roque da Silva. [S.I.]: Ed. Ridendo Castigat Mores, [19--?]. 